\title{
Post WWII Japan-Taiwan Economic Relations Development and Future Direction
}

\author{
Hsiung-shen Jung ${ }^{1}$, Shin-Fa Tseng ${ }^{2}$ \\ ${ }^{1}$ Department of Applied Japanese, Aletheia University Chinese Taipei; ${ }^{2}$ Department of Applied Foreign Languages, Minghsin Uni- \\ versity of Science and Technology Chinese Taipei. \\ Email: hsjung.26@msa.hinet.net, sft@must.edu.tw
}

Received 2013

\begin{abstract}
Japan's victory in the Sino-Japanese War of 1894-1895 lead to 50 years of colonial rule of Taiwan. The industrial hardware facilities and equipment left behind by the Japanese withdrawal from Taiwan after the World War II (WWII) provided Taiwan with a basis for industrial development. The frequent economic exchanges between Taiwan and Japan economies, even before the Second World War, became stagnant with the withdrawal of Japan from Taiwan after the war. Afterwards, due to the outbreak of the Korean War, a large number of special needs promoted the rapid growth of the Japanese economy, which led to the economic development of Taiwan and other Asian countries. Once again, Taiwan and Japan were economically joined and exchanges became even more active, as compared to the situation before World War II. The success of Taiwan's economic development still cannot escape the trade and economic development model highly dependent on the United States of postwar Asian countries, in particular, foreign capital is a very important factor. Japanese capital, ranking the second place in foreign investments in Taiwan, is one of the indispensable factors. On the other hand, the opening up of the Chinese market has given a great deal of room for cooperation between Taiwanese and Japanese enterprises adept in direct investment.
\end{abstract}

Keywords: ODA; Japanese Assistance; the Taiwan-Japan Economic Cooperation; Chiwan

\section{Introduction}

Since its World War II defeat and the success of economic reconstruction, Japan started to provide foreign economic assistance, officially started in the participation of 1954 Colombo Plan and the signing of the Myanmar Compensation Agreement [1]. In the early period, technical cooperation was implemented in postwar compensations for Asian countries; however, the aid of this period was the promotion of an export policy.

As shown in Tables 1 and 2, the first loan to India in 1958 was the official beginning of ODA (Official Development Assistance) of Japan [2]. Japanese assistance payments increased over the years, amounting to USD 8.965 billion in 1989, and ranked the first in the world by being more than USD 7.664 billion over the United States.According to the data of the Intelligence and Analysis Service of the Ministry of Foreign Affairs of Japan, from 1967 to 1971, the Japanese overseas economic aid amounted to USD 7.07billion, and the percentage at $6.5 \%$ of the total sum to Taiwan (USD 0.45 billion) was considerably low, as compared to the percentage to Hong Kong at $8.4 \%$, South Korea at $12.5 \%$, Indonesia at $8.8 \%$, and the Philippines at $7.8 \%$. However, the aid was an extremely great contribution to the economic development of Taiwan at that time [3]. As shown in Table 1, the amount of Japanese ODA remained unchanged over the years. The interactions between Taiwan and Japan were suspended, along with Japanese aid in 1972, when Taiwan and Japan severed diplomatic relations. Afterwards, the Japanese governmental economic assistance was replaced by exchange foundations. However, the unofficial investment, which began before the breakoff of diplomatic relations, remained active.

Table 1. The amount of Japan's overseas aid by year Unit: USD million.

\begin{tabular}{cccccc}
\hline Year & 2002 & 2003 & 2004 & 2005 & 2006 \\
\hline Amount & 9,283 & 8,880 & 8,992 & 13,126 & 11,136 \\
Year & 2007 & 2008 & 2009 & 2010 & 2011 \\
& & & & & \\
Amount & 7,697 & 9,601 & 9,467 & 11,021 & 10,604 \\
\hline
\end{tabular}

Source: Ministry of Foreign Affairs of Japan ODA. http://www.mofa.go.jp/mofaj/gaiko/oda/index.html 
Table 2. Comparison of ODA amount of major countries in 2011 Unit: USD million.

\begin{tabular}{ccccccc}
\hline No. & Country & Actual amount & Proportion & Growth rate over the previous year (\%) & Ratio against GNI & Ranking \\
\hline 1 & The United States & 30,745 & $23.0 \%$ & $1.3 \%$ & $0.20 \%$ & 19 \\
2 & Germany & 14,533 & $10.9 \%$ & $11.9 \%$ & $0.40 \%$ & $0.56 \%$ \\
3 & England & 13,739 & $10.3 \%$ & $5.3 \%$ & $0.6 \%$ & $0.46 \%$ \\
4 & France & 12,994 & $9.7 \%$ & $-3.8 \%$ & $0.18 \%$ & 10 \\
5 & Japan & 10,604 & $7.9 \%$ & 21 \\
\hline
\end{tabular}

Source: Ministry of Foreign Affairs of Japan ODA, http://www.mofa.go.jp/mofaj/gaiko/oda/index.html

\section{Motivation and Purposes}

In recent years, due to China's rapid economic development, many Japanese companies specified Taiwan as a forward base with the same culture and language as mainland China. Japanese companies employed Taiwanese personnel that understood Japanese business culture and the Japanese language, as well as Chinese language and culture, and furthermore, successfully and smoothly transferred technology and management to mainland China.

As shown in Table 3-1 and Table 3-2, there has been a great problem of economic and trade deficit between Taiwan and Japan for years. Japan is Taiwan's second largest trading partner and the main source of foreign capital and technology. According to the Statistics of the Bureau of Foreign Trade, the 2010 Taiwan-Japan bilateral trade volume was nearly USD 70 billion. In terms of the amount of the balance of trade, the 2011 Japan to Taiwan trade surplus amounted to USD 27.61 billion. In 2011, Japan mainly exported to countries/regions by volume, as follows, mainland China, the United States, the 10 ASEAN nations, 27 member states of the European Union, South Korea, and Taiwan, in proportions of $19.7 \%, 15.3 \%, 15.0 \%, 11.6 \%, 8.0 \%$, and $6.2 \%$, respectively. In 2011, Japan's five major sources of imports, in order, were China, the 10 ASEAN countries, 27 member states of European Union, the United States, and Australia, in proportions of $21.5 \%, 14.6 \%, 9.4 \%, 8.7 \%$, and $6.6 \%$, respectively. Taiwan was ranked from No. 10 in 2010 to No. 14 (surpassed by Malaysia, Qatar, Thailand, and Germany), with its proportion reduced from 3.3\% to $2.7 \%$.

By observing Japan's trade relations with Taiwan's major trade competitors in 2011, such as South Korea, Singapore, and Hong Kong, it can be found that Taiwan's proportions of export and import were lower than South Korea, and ranked in second place. In terms of export growth rate, Taiwan was the only one of the Four Asian Tigers to be negative in growth. In addition, Taiwan ranked last in terms of import expansion rate, by falling far behind South Korea, Singapore, and Hong Kong.
Table 3-1. Statistics of Japan's Trade with countries in the world in 2011 Unit: USD million; \%.

\begin{tabular}{lccc}
\hline \multirow{2}{*}{ Country/region } & \multicolumn{3}{c}{ Trade volume } \\
\cline { 2 - 4 } & Amount & Growth rate & Proportion \\
\hline Taiwan & $74,113.1$ & -1.8 & 4.4 \\
Hong Kong & $44,520.3$ & 1.6 & 2.7 \\
Korea & $105,923.0$ & 16.5 & 6.3 \\
Singapore & $35,943.2$ & 7.7 & 2.1 \\
The United States & $200,560.3$ & 7.8 & 11.9 \\
Canada & $21,887.7$ & 8.0 & 1.3 \\
NAFTA & $240,288.5$ & 7.8 & 14.3 \\
China & $346,141.8$ & 14.2 & 20.6 \\
World & $1,679,589.9$ & 14.7 & 100.0 \\
\hline
\end{tabular}

Table 3-2. Statistics of Japan's Trade with countries in the world in 2011 Unit: USD million; \%.

\begin{tabular}{ccccccc}
\hline \multirow{2}{*}{$\begin{array}{c}\text { Country/ } \\
\text { region }\end{array}$} & \multicolumn{3}{c}{ Export } & \multicolumn{4}{c}{ Import } \\
\cline { 2 - 7 } & Amount & $\begin{array}{c}\text { Growth } \\
\text { rate }\end{array}$ & Proportion & Amount & $\begin{array}{c}\text { Growth } \\
\text { rate }\end{array}$ & Proportion \\
\hline Taiwan & $50,862.8$ & -3.0 & 6.2 & $23,250.3$ & 0.7 & 2.7 \\
Hong Kong & $42,976.2$ & 1.6 & 5.2 & $1,544.1$ & 1.6 & 0.2 \\
Korea & $66,087.6$ & 6.1 & 8.0 & $39,835.4$ & 39.0 & 4.7 \\
Singapore & $27,264.8$ & 8.0 & 3.3 & $8,678.4$ & 6.4 & 1.0 \\
The United & $126,074.8$ & 6.2 & 15.3 & $74,485.4$ & 10.4 & 8.7 \\
States & & & & & & \\
Canada & $8,927.1$ & -4.2 & 1.1 & $12,960.6$ & 18.4 & 1.5 \\
NAFTA & $147,087.9$ & 5.5 & 17.9 & $93,200.6$ & 11.6 & 10.9 \\
China & $162,013.1$ & 8.2 & 19.7 & $184,128.6$ & 20.0 & 21.5 \\
World & $823,544.1$ & 6.9 & 100.0 & $856,045.8$ & 23.3 & 100.0 \\
\hline
\end{tabular}

Note: 1 . APEC currently has 21 members, along with those listed in the table; Brunei and Papua New Guinea are also member states of APEC. 2. ASEAN currently has 10 member states, along with those listed in the table, Myanmar, Laos, Cambodia, and Brunei are also ASEAN member states. Source: Japan Customs Data. 


\section{Prepare Literature Review}

Regarding studies of Taiwan's economy, [4] focused on the pre-war Japanese construction and development of Taiwan. [5] discussed the industrialization of Taiwan after WWII. Sun (1983) focused on the technical cooperation of Japan and Taiwan. On the other hand, regarding studies on the Japan-Taiwan alliance, [6] argued that, although Japanese enterprises started to invest in China and tap the Chinese market earlier than Taiwanese enterprises, their performance is poorer due to major reasons, such as a lack of understanding of the social conditions of China regarding aspects including, customary commercial practices, labor management, human resource structure, etc., coupled with a lack of flexibility for business management of Japanese businesses, meaning it is extremely difficult to adapt to rapid environmental changes in China. in recent years, Japanese enterprises gradually paid increasing attention to the huge domestic market in China and attempted to expand sales in China, resulting in major business operational problems, while Taiwan has similar cultural habits, ideas, and behavior patterns, but without the language barrier; therefore, Taiwanese enterprises are more active in China [6].[7] pointed out that cross-strait economic cooperation has been noted by various countries, as evidenced by the emergence of the new term Chiwan (China + Taiwan). The term was coined by the Chosun Ilbo of South Korea, when warning South Korea businesses to pay attention to the Sino-Taiwan Industrial Cooperation [7]. However, to Japan and Taiwan, it might be a business opportunity. Japan-Taiwan economic cooperation started before the war, by a hundred years, and has developed to become known as "investment in China by taking advantage of Taiwan". [8] argued that this is because Taiwan is an important location of overseas branches of Japanese enterprises, major destination of technology supply, and the historical background of close trade relations between Taiwan and Japan [8].

Run-tsu Peng, president of the Association of East Asian Relations, Ministry of Foreign Affairs, and Mitsuo Ohashi, the new president of the Interchange Association of Japan, signed on September 22, 2011, on behalf of the two countries, "Agreement between the Association of East Asian Relations, Ministry of Foreign Affairs of the Republic of China and the Interchange Association of Japan on Investment Liberalization, Promotion, and Protection". The Ministry of Foreign Affairs said that this agreement would further strengthen the economic and trade cooperation between Taiwan and Japan, and the resulting niche to both countries was very significant. after the 311 earthquake, the Japanese raw material supply chains were broken, and Japanese industry realized that Taiwan would be the ideal "backup location" for Japan, providing Taiwan and Japan sign an invest- ment agreement to bring Taiwan-Japan relations even closer.

\section{Research and Analysis}

During the Japanese colonial era in Taiwan, Japan implemented all types of construction, including railway, highway, post office, and telephone services of great contribution to economic development for the purpose of colonial exploitation [4]. After the outbreak of the war in the Pacific, Taiwan became Japan's base for marching into the South [5]. Economic relations between Taiwan and Japan originated in the prewar colonial era were interrupted by the withdrawal of Japanese businesses due to Japan's defeat in 1945. However, the relations were soon resumed after the war, and the postwar economic relations between Taiwan and Japan were expanded and deepened.after the Plaza Accord of G5 in 1985. In the face of the adjustment in the exchange rate of the U.S. dollar, crude oil prices plunged, the level of international interest rates reduced, and the United States-Japan-NIEs Pacific Triangle's interdependence relationships were gradually strengthened, giving rise to great economic force in the region. The Taiwan-Japan relations were included in this framework and became more substantial in quality and quantity.

In the structure of "importing capital goods and intermediate goods from Japan, and exporting products overseas", the pattern of "increased exports of Taiwan led to increased imports from Japan" became the major cause of the trade balance with Japan. Regarding the trade imbalance between Taiwan and Japan since the 1980s, by 1985 it amounted to about USD 2 billion to USD 3 billion. However, since 1986, the trade imbalance had been on the rise. In particular, with the implementation of Taiwan's "National Construction Six-year Plan” (1991 96), when Taiwan imported machinery and equipment from Japan, the Japanese economy fell into recession, causing the condition to worsen.

Regarding the yearly increase of trade imbalance, how Japan addresses the problem is an issue that cannot be ignored. Among the causes for the inability to solve the problem, the issue of Taiwan's economic structure plays a very large part. In particular, due to the increase of Chinese exports to Japan, the market share of Taiwanese products in the Japanese market reduces due to the competition of Chinese products, most of which are laborintensive, low capital, and low technology products.

\section{Japanese Enterprises' Investment in Taiwan}

Due to geographical convenience, Asia is Japanese enterprises' most important overseas direct investment destination for most branch offices and factories. In retros- 
pect, before WWII, Japan invaded and exploited countries across Asia, especially primary industry natural resources in Southeastern nations, in order to support its warfare in East Asia. After the war, by direct overseas investment, Japanese companies produced and sold products around the world by taking advantage of the cheap labor in Asia. Afterwards, with rising living standards in Asian countries, Japan expects to dominate the Asian consumption market through department store businesses of the tertiary industry.

In the above mentioned three waves of Japanese domination of Asia, Taiwan was and is an important stronghold of Japanese companies. The reasons beyond the geographic closeness of Taiwan and Japan include the cheap labor and abundant supply of talents with production skills and language proficiency. Therefore, from a very early time, Taiwan became the best overseas stronghold of Japanese enterprises. For example, Nissan's first overseas cooperative partner is Yulon Motors of Taiwan.

The postwar Japanese investment in Taiwan began in 1953. However, investment activities did not become active until the formulation of the "Investment Incentive Ordinance" and the establishment of the Kaohsiung Export Processing Zone in the 1960s. In 1972, due to breakoff of diplomatic relations with Japan, the amounted was reduced to $1 / 3$ of that in 1970, to USD 7.73 million. As the impact was temporary, the investment amount expanded once again in the following year. Since the Plaza Accord in 1985, and with the appreciation of the Japanese Yen and the depreciation of the USD, coupled with the globalization of Japanese enterprises, Japanese investment in Taiwan was accelerated, and peaked for the second time in 1990, amounting to USD 838,940, 000.

According to the Council for Economic Planning and Statistics, after the 311 major earthquake of Japan in 2011, Japanese companies accelerated its overseas layout bases, and especially, as the yen continues to rise, the signing of ECFA and the Taiwan-Japan investment agreement, Taiwan becomes the preferred choice of Japanese overseas investment. Last year alone, for the first time, cases of Japanese investment in Taiwan exceeded 400 , and the investment amount increased by $11 \%$, while Taiwan's investment in Japan grew substantially by more than five times.

From the primary industry in prewar times to the secondary industry shortly after WWII and to the late stage of the tertiary industry, from resource development to labor acquisition to market share, Japan's investment in Taiwan originally concentrated on manufacturing; however, with the gradual expansion of the domestic needs of Taiwan, for example, in the mid-1980s, the then Evergreen Department Store and Japan's Tokyu Group jointly opened cooperation between Japanese and Taiwanese department store businesses. Since then, Japan-Taiwan joint ventures and cooperative department stores appeared one after another. In a very short period of time, Japan's major department stores appeared in Taiwan in clusters. Enterprises from Japan and Taiwan did businesses separately on mainland China. Without technological cooperation, technology-intensive manufacturing businesses can easily produce products of poor quality, while department stores in the service industry can do business according to their own experiences. The smooth development of Taiwan's domestic Far East Department Store on mainland China, with its experience over years of business operations, can be regarded as a successful example.

Taiwan's industrialization further strengthens the Taiwan-Japan economic relationship, and Japan has played an important function of supplying technology. After WWII, Taiwan received technology supplies from various countries, including the UN, most significantly, from Japan. This supply was similar to the prewar period, with Taiwan as the receptor and Japan as the supplier. In accordance with the "Sino-Japanese Technical Cooperation Program”, 380 Japanese technicians and experts (1961 76) were dispatched to Taiwan. The number was even greater than the 346 personnel sent by the UN under the "UN Technology Assistance Program" (1952 71). In accordance with the "Sino-Japanese Technical Cooperation Program", and in addition to providing vocational training center technicians, experts, and donating equipment, Japan also assisted Taiwan in setting up vocational training centers in northern, central, and southern regions in Taiwan, which had a very deep impact on industrial talent cultivation in Taiwan.

\section{Conclusions and Suggestion}

In the early stages of economic development, Taiwan attracted capital and technology from around the globe through inexpensive land, a quality labor force, and other business elements, as the overseas production bases of various countries to enhance and improve industrial competition conditions. With the rise in land prices and salaries in Taiwan, and increased awareness of environmental protection and labor welfare, Taiwan's investment environment changed greatly. Meanwhile, as the investment environments in China and Southeast Asian countries were improved, governments actively introduced foreign capital, resulting in decreased foreign investment in Taiwan, in terms of both the number of cases and monetary amounts. In addition to foreign capital, Taiwan's investors came to realize the changes in the domestic investment environment and continuously transferred manufacturing bases of labor intensive industries without international competitiveness to China or Southeastern Asian countries with cheaper labor. Some 
companies had to upgrade labor-intensive industries into capital and technology intensive industries.

Taiwan and Japan are closely joined due to historical factors. Before WWII, Taiwan helped the Japanese militarily, while Japan economically helped Taiwan after WWII. The Taiwan-Japan relations are mutually beneficial if the two are on good terms, otherwise, the relations will be mutually harmful. Although Japanese enterprises made great contribution to Taiwan's economy, in terms of employment and technological aspects after WWII, in the background of expanding the Taiwan-Japan trading volume, and on the premise of solving the trade deficit with Japan, how to find a new method suitable for both parties is an issue of top priority at present. From prewar times to the postwar era, from the primary industry to the tertiary industry, from the colonial economy before WWII to the current horizontal labor division economy, Japan and Taiwan may march in the direction of cooperation in joint economic development.

From the flying geese model of economic development to the industrial division, "Investment Protection Agreement to Strengthen Economic and Trade Cooperation" is the first agreement between Japan and Taiwan that promotes and protects investment of indicative significance. Meanwhile, it is a major progress of the overall economic development strategy of "Strength Taiwan, Link to the Asia-Pacific, and Lay out in the World".

On September 22, 2011, the representatives of both Taiwan and Japan signed the "Taiwan-Japan Investment Agreement”. The contents of the agreement consist of investment promotion, investment protection, and investment liberalization. In addition, after the agreement came into effect, Taiwan and Japan granted investors from each country "national treatment" and "most favored nation treatment", thus, ensuring free access of investment capital. Regarding this agreement, Taiwan's public opinion believed it a significant progress in for- eign trade relations, and had high expectations of the signing of the Taiwan-Japan free trade agreement. Japan expected Taiwan to be a powerful alternative to Japan's overseas production base in response to external factors, such as the rising value of the Yen.

Taiwan and Japan are quite high in the complementary nature of industrial structures, and via the Taiwan-Japan investment agreement, the two sides industries will further strengthen cooperation and enhance their willingness to invest, eliminate barriers to investment, and protect investors' interests, and thus, enhance mutual investment to bring about the following benefits: (1) to provide both stable and institutionalized investment environments; (2) to promote the Taiwan-Japan industrial supply chain to become more closely linked; and (3) to establish a way to resolve international arbitration of investment disputes.

\section{REFERENCES}

[1] S. Nagano, and M. Knodo, M. Japan's postwar reparations---start of Asia's economic cooperation. Keisoshobo Publishing, 1992, pp.253 p161

[2] T. Fujino. Review of Japan ODA policy and future directions---strategic ODA and national support as a policy. 2005, 40

[3] The Intelligence and Analysis Service of the Ministry of Foreign Affairs of Japan. Japan's Economic Cooperation. 1972, 58.

[4] C. H. Lin. “A Historical Review of Taiwan's Economic Development” Interchange Association of Japan, 2002, 258

[5] L. S. Song. "Preliminary Technological Conditions for Postwar Industrialization of Taiwan” , The Economics Society, Meiji Gakuin University, Econ Study 1996, 107: 26

[6] Y. Chu. Taiwanese-Japanese enterprise alliance in commerce in China. (research report) 2004, 23 